Kajian Jurnalisme

ISSN 2549-0559 (cetak) ISSN 2549-1946 (online)

Volume 03 Nomor 01 Tahun 2019

\title{
Penggunaan Twitter Sebagai Medium Distribusi Berita dan Newsgathering oleh Tirto.id
}

\author{
Nadia Araditya Paramastri dan Gumgum Gumilar \\ Program Studi Jurnalistik, Fakultas Ilmu Komunikasi, Universitas Padjadjaran \\ E-mail: aradityayik@gmail.com
}

\begin{abstract}
This study aims to determine how Twitter is used by Tirto.id as a distribution and newsgathering medium, as observed from the reasons Tirto.id used to choose the distribution medium, the workflow and strategies Tirto.id is using with Twitter, the process of newsgathering using Twitter and the process of Twitter usage by Tirto.id as a two-way communication with readers. This research uses the qualitative method with an intrinsic model from Robert E. Stake as a model approach. The results showed that the main reason why Tirto.id used Twitter is because of the suitability with Tirto.id's background as an online mass-media that need a driving tool for the youth social changes. In its workflow, the Editorial team and Social Media Division worked separately, but still linked to each other. The editorial team needed reader's fast response with Twitter for the newsgathering, while Social Media Division used it to distribute the information and watch the readers' feedback from it. This feedback will be used as an input for the Editorial team.
\end{abstract}

Keywords: twitter, Tirto.id, news

\begin{abstract}
Abstrak
Penelitian ini bertujuan mengetahui bagaimana penggunaan Twitter oleh Tirto.id sebagai medium distribusi berita dan newsgathering, ditinjau dari landasan Tirto.id dalam memilih medium, proses alur kerja dan strategi Tirto.id dalam menggunakan Twitter sebagai alat penggerak perubahan sosial, penggunaan Twitter oleh Tirto.id dalam kegiatan newsgathering, dan proses penggunaan Twitter oleh Tirto.id sebagai saluran komunikasi dua arah dengan audiens. Untuk menguraikannya, peneliti menggunakan metode penelitian kualitatif dengan pendekatan studi kasus intrinsik dari Robert E. Stake. Hasil penelitian ini menunjukkan bahwa Tirto.id menggunakan Twitter karena kesesuaiannya dengan latar belakang Tirto.id sebagai media online yang membutuhkan alat penggerak perubahan sosial bagi generasi muda. Dalam proses kerjanya, tim redaksi dan tim media sosial bekerja terpisah, namun saling bekerja sama. Tim redaksi membutuhkan interaktivitas dan respons audiens yang cepat melalui Twitter untuk mengumpulkan bahan berita dan memilih narasumber, sementara Tim Redaksi menggunakan Twitter untuk distribusi berita, sekaligus melihat feedback audiens terhadap berita tersebut. Feedback yang didapatkan tim media sosial melalui Twitter akan menjadi masukan bagi tim redaksi.
\end{abstract}

Kata Kunci: twitter, Tirto.id, berita 
19| Kajian Jurnalisme

ISSN 2549-0559 (cetak) ISSN 2549-1946 (online)

Volume 03 Nomor 01 Tahun 2019

\section{Pendahuluan}

Perkembangan internet memungkinkan penyebaran informasi secara cepat, luas, dan mudah. Hal tersebut dimanfaatkan oleh media massa untuk memenuhi kebutuhan masyarakat terhadap informasi. Berdasarkan hasil riset dari APJII tahun 2016 tentang perilaku pengguna internet di Indonesia, pengguna internet di Indonesia sudah mencapai 132,7 juta dari total populasi penduduk Indonesia yang mencapai 256,2 juta orang. Sebanyak 97,4 persen masyarakat menggunakan internet untuk mengakses media sosial, dan 96,4 persen, atau setara dengan 127,9 juta pengguna juga menggunakannya untuk mengakses berita. Terdapat beragam motif pengguna internet dalam mengakses berbagai media, termasuk media sosial. Salah satu motif utama adalah adanya fasilitas pendukung yang memungkinkan mereka mengakses dan melakukan interaksi di dalam media sosial (Nugraha \& Akbar, 2019).

Mencita-citakan jurnalisme yang jernih dan mencerahkan, Tirto.id berdiri sebagai media online pada bulan April 2016 (Tirto.id, 2016). Belum genap berusia 9 bulan, Tirto.id mendapatkan penghargaan sebagai website berita dan media terbaik dalam ID Website Awards oleh Pengelola Nama Domain Internet Indonesia (PANDI).

Tirto.id percaya bahwa tulisan dengan data yang kuat dan disampaikan dengan baik dan cepat merupakan sumber informasi yang layak bagi masyarakat yang akan berpengaruh dalam pengambilan keputusan dan pengendali perubahan. Untuk menyebarkan tulisannya tersebut, Tirto.id memanfaatkan media sosial seperti Facebook, Twitter, Google+, LinkedIn, Instagram, dan YouTube. Namun, Tirto.id tidak hanya menggunakan fitur Twitter sebagai medium distribusi beritanya, tetapi juga sebagai medium untuk kegiatan newsgathering.

Twitter berawal dari layanan jejaring sosial berbentuk micro-blogging yang dibuat pada tahun 2006 oleh Jack Dorsey, Biz Stone, dan Evan Williams. Pada mulanya, Twttr, nama awal Twitter ketika digagas, dibuat sebagai sebuah layanan SMS (short message service) agar dapat berkomunikasi dalam sekelompok kecil (Elcom, 2010). Berbagai aktivitas yang dilakukan Twitter merupakan bagian dari Computer Mediated Communication (CMC), sebuah proses komunikasi manusia melalui computer yang melibatkan khalayak, tersituasi dalam konteks tertentu, di mana proses itu memanfaatkan media untuk tujuan tertentu (Nasrullah, 2016).

Pemanfaatan fitur dan kegunaan Twitter oleh beragam kegiatan jurnalistik oleh Tirto.id tersebut dibedah oleh peneliti menggunakan teori ekologi media atau dikenal juga dengan sebutan technological determinism. Teori tersebut dicetuskan oleh pemikir dari Kanada Marshall McLuhan dalam Understanding Media (1964), memaparkan tentang pengaruh teknologi komunikasi terhadap manusia. Beberapa peneliti menyebut pemahaman tersebut sebagai teori ekologi media. Para peneliti yang mengkaji ekologi media beranggapan bahwa teknologi dan teknik, mode informasi dan kode komunikasi memiliki peran penting dalam kehidupan manusia. Menurut McLuhan, manusia memang termodifikasi oleh teknologi saat menggunakannya, dalam hal ini manusia menjadi objek pasif. Tetapi, manusia akan selalu menemukan cara baru untuk memodifikasi teknologi yang digunakan, dimana manusia kembali pada posisi sebagai subjek (Morissan; Wardhani, Andi, Corry; Hamid, 2013). Tentang pemanfaatan Twitter, dalam penelitiannya, Eddyono menyebutkan bahwa Twitter masih 
berpeluang menjadi sumber informasi baru sekaligus menjadi media sosialisasi dan interaksi. Namun, Twitter juga memiliki peluang sebagai pesaing media massa mainstream. Media massa menggunakan fitur Twitter yang ada untuk memanfaatkan kekuatan Twitter (Eddyono, Subarkah, 2013).

Penggunaan Twitter sebagai salah satu cara untuk menciptakan konten berita dinilai sebagai sesuatu yang baru oleh Head of Partnership Twitter Indonesia Teguh Wicaksono. Teguh menilai Tirto.id adalah media yang aktif untuk berinovasi dan bereksperimen dengan Twitter. Selain itu, Teguh juga melihat konten Tirto.id sebagai konten yang berkualitas, terlebih melihat penggunaan infografis dalam setiap beritanya. Melihat hal tersebut, Twitter kemudian memasukkan Tirto.id sebagai salah satu rekan untuk Twitter dengan memberikan akses khusus untuk dapat menggunakan fitur terbaru Twitter, yaitu fitur Twitter Moments. Akses tersebut terbatas hanya untuk sebelas media tingkat satu, dan Tirto.id merupakan media termuda yang ada di antara jajaran media lainnya.

Tirto.id menggunakan komunikasi dua arah melalui media sosial baik untuk distribusi berita maupun kegiatan newsgathering. Untuk mengumpulkan bahan berita, reporter Tirto.id salah seorang reporter Tirto.id mencari narasumber yang akan diwawancarai untuk berita Tirto.id melalui cuitan yang dikeluarkan melalui akun Twitter-nya. Selain itu, Tirto.id juga menggunakan fitur baru Twitter Polling.

Sementara itu, untuk distribusi berita, Tirto.id menggunakan cuitan yang mengandalkan hyperlink, serta melampirkan foto, grafis, hingga gif. Tirto.id juga menggunakan fitur-fitur baru seperti $Q \& A$ untuk membuka sesi tanya jawab antara audiens dengan narasumber. Misalnya, Tirto.id membuka sesi tanya-jawab yang mengandalkan cuitan dan video dengan narasumber Menteri Komunikasi dan Informatika Rudiantara, ketika memeringati Hari Belanja Online Nasional. Tirto.id menggunakan Twitter sebagai cara untuk memenuhi visi misinya, yaitu menyediakan berita online yang berkualitas dengan mengandalkan data dan jurnalisme presisi. Tirto.id percaya bahwa tulisan yang berkualitas yang disampaikan dengan baik dapat membuat perubahan untuk generasi yang lebih baik. Tulisan tersebut dimaksudkan untuk melawan berita bohong (hoax). Menurut hasil riset Masyarakat Telematika Indonesia (Mastel), sebanyak 92,4 persen masyarakat mendapatkan hoax dari media sosial. Dari hasil riset yang sama pun, sebanyak 70,2 persen masyarakat sangat setuju bahwa hoax dapat menghambat pembangunan. Penggunaan Twitter sebagai salah satu alat penggerak perubahan sosial tersebut peneliti kaji dengan metodologi penelitian kualitatif dengan pendekatan studi kasus intrinsik Robert E. Stake untuk mendapatkan pemahaman mendalam.

\section{Metode}

Penelitian ini menggunakan metodologi penelitian kualitatif untuk mencari tahu tahu tindakan redaksi Tirto.id, termasuk persepsi atau motivasi dari redaksi mengenai kebijakan yang diambil dalam penggunaan teknologi komunikasi, yaitu Twitter dalam memenuhi visi dan misinya. Seperti dinyatakan Moleong, penelitian kualitatif bermaksud untuk memahami fenomena tentang apa yang dialami oleh subjek penelitian misalnya perilaku, persepsi, motivasi, tindakan, dll., secara holistik, dan dengan cara deskripsi dalam bentuk kata-kata dan 
21| Kajian Jurnalisme

ISSN 2549-0559 (cetak) ISSN 2549-1946 (online)

Volume 03 Nomor 01 Tahun 2019

bahasa, pada suatu konteks khusus yang alamiah dan dengan memanfaatkan berbagai metode alamiah (Moleong, 2010) .

Penelitian ini menggunakan metode pendekatan studi kasus intrinsik dari Robert E. Stake. Stake mengungkapkan bahwa pengetahuan merupakan sebuah hal yang dibentuk, bukan ditemukan. Pandangan tersebut sejalan dengan penelitian ini karena berlandaskan paradigma konstruktivis, sehingga peneliti menggunakan studi kasus dari Robert E. Stake. Studi kasus intrinsik merupakan kajian studi kasus yang berlandaskan tujuan peneliti yang ingin memahami sebuah kasus tertentu. Fokus studi kasus intrinsik ada pada kasusnya. Studi kasus ini dipilih ketika peneliti memiliki minat terhadap kasus tersebut. Peneliti mendalami penggunaan media sosial, yaitu Twitter, oleh media baru (media online) Tirto.id dalam kegiatan jurnalistiknya sebagai medium distribusi berita dan newsgathering, karena latar belakang Tirto.id sebagai media baru dan berusia muda namun dapat menjadi partner resmi dari Twitter.

Informan dalam penelitian ini adalah Pemimpin Redaksi sekaligus CEO Tirto.id, reporter Tirto.id, administrator Twitter Tirto.id, serta Head of Partnership Twitter Indonesia. Pemilihan informan tertentu karena dianggap memahami objek penelitian, sehingga individu tidak dipilih secara acak. Informan dalam penelitian ini diposisikan sebagai subjek penelitian yang mengerti tentang penggunaan Twitter oleh Tirto.id maupun dibalik pertimbangan penggunaan Twitter itu sendiri.

\section{Hasil dan Pembahasan}

Pertimbangan Tirto.id untuk menggunakan Twitter dilakukan dalam rapat redaksi. Dari pertimbangan tersebut, Tirto.id menjadikan Twitter sebagai medium distribusi berita dan newsgathering karena dianggap dapat membuat pekerjaan menjadi lebih efisien. Mereka merasa Twitter tepat untuk sasaran mereka, yaitu generasi milenial, mahasiswa khususnya, yang berusia 18-35 tahun, karena milenial dianggap senang berpendapat.

Dengan menggunakan Twitter, tanpa harus turun ke lapangan atau bertatap muka, reporter dapat menemukan narasumber yang kredibel untuk bahan berita. Reporter dapat membuat lebih banyak berita dengan memangkas waktu turun ke lapangan dengan melemparkan cuitan di Twitter dan memilih narasumber untuk diwawancarai kemudian. Begitu juga dengan administrator Twitter yang bisa menggunakan berbagai jenis media, seperti teks, audio, gif, video dengan Twitter. Respons audiens yang didapatkan bisa beragam, seperti balasan cuitan yang dapat berupa masukan atau kritikan yang bersifat asynchronous. Masukan tersebut akan dibahas pada tahap controlling dalam proses manajemen Tirto.id.

Penggunaan Twitter, sebagai teknologi komunikasi telah menunjukkan bahwa Twitter merupakan penguatan dari teknologi sebelumnya, yaitu komunikasi dua arah antara media massa dengan audiens yang terhubung melalui internet. Penggunaan teknologi komunikasi yang didasarkan oleh alasan Tirto.id, seperti memangkas waktu pengerjaan berita dengan berkomunikasi melalui internet menunjukkan bahwa Tirto.id meninggalkan beberapa tradisi atau budaya komunikasi dalam media massa, yaitu komunikasi tatap muka langsung. Budaya baru, komunikasi melalui internet, telah membuat kinerja yang lebih efisien bagi pekerjanya tanpa harus repot turun ke lapangan untuk bertemu beberapa narasumber. Budaya komunikasi 
ini juga meninggalkan komunikasi satu arah yang selama ini berlangsung antara media massa dan audiensnya. Tirto.id menggunakan Twitter justru untuk menimbun respons dan feedback dari audiensnya, baik untuk kepentingan newsgathering yang berupa jawaban dari pertanyaan ataupun kepentingan distribusi berita yang berupa masukan-masukan.

Penggunaan Twitter sebagai medium distribusi berita dan newsgathering yang mengandalkan komunikasi dua arah, dapat membuat adanya perang cuitan, atau tweet war, yang terjadi di antara audiens dan Tirto.id. Namun, seperti apa yang diungkapkan oleh pemimpin redaksi, komunikasi dua arah boleh saja dilakukan antara audiens dengan pihak Tirto.id, namun ketika sudah mulai memanas, maka harus disudahi agar menjaga hubungan dengan audiens. Adanya perang cuitan tersebut merupakan sebuah bentuk dari hukum reversal, yaitu sebuah keadaan di mana artefak tersebut justru memutarbalikkan keadaan. Ketika sebuah artefak seharusnya menjalankan fungsinya, yaitu Twitter sebagai medium distribusi berita dan newsgathering, namun justru menjadi arena perang cuitan.

Kegunaan Twitter lain yang dimanfaatkan oleh Tirto.id adalah kemampuannya untuk mengumpulkan informasi dari publik. Dalam hal ini, Tirto.id sebagai perusahaan media, menggunakan Twitter untuk kegiatan newsgathering atau pengumpulan berita. Pengumpulan berita melalui Twitter tersebut dilakukan dalam beberapa cara.

Pertama, pihak Tirto.id menggunakan fitur polling. Melalui tweet yang menyajikan pertanyaan dan beberapa jawaban yang bisa dipilih, Tirto.id akan melemparkan suatu isu. Misalnya, menyambut Harbolnas, Tirto.id mengeluarkan riset kecil-kecilan.

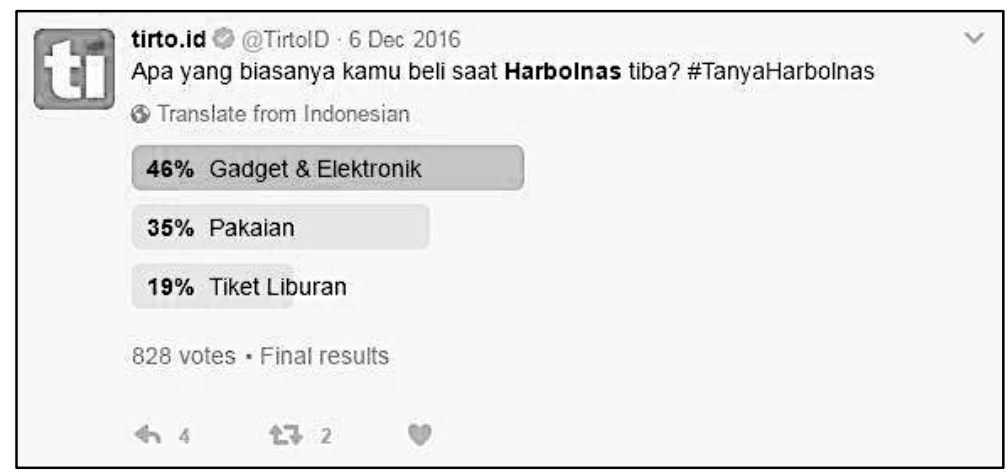

Gambar 1 Fitur polling yang dilakukan dalam menyambut Harbolnas

(Sumber: twitter@tirtoID)

Hasil dari penggunaan fitur polling tersebut dapat dijadikan pengantar atas suatu isu yang akan dibahas oleh Tirto.id. Menurut salah seorang reporter Tirto.id, hasil polling tersebut memang tidak dijadikan bahan berita secara harfiah. Namun, hasil polling yang merupakan respons masyarakat tersebut dapat kemudian dieksplor lebih lanjut oleh Tirto.id untuk bisa dikerjakan sebagai usulan berita. Selain itu, Tirto.id pernah mengeluarkan \#TirtoIDMendengarkan sebagai salah satu upaya untuk memenuhi kebutuhan pembaca terhadap informasi yang diinginkan. 
23 | Kajian Jurnalisme

ISSN 2549-0559 (cetak) ISSN 2549-1946 (online)

Volume 03 Nomor 01 Tahun 2019

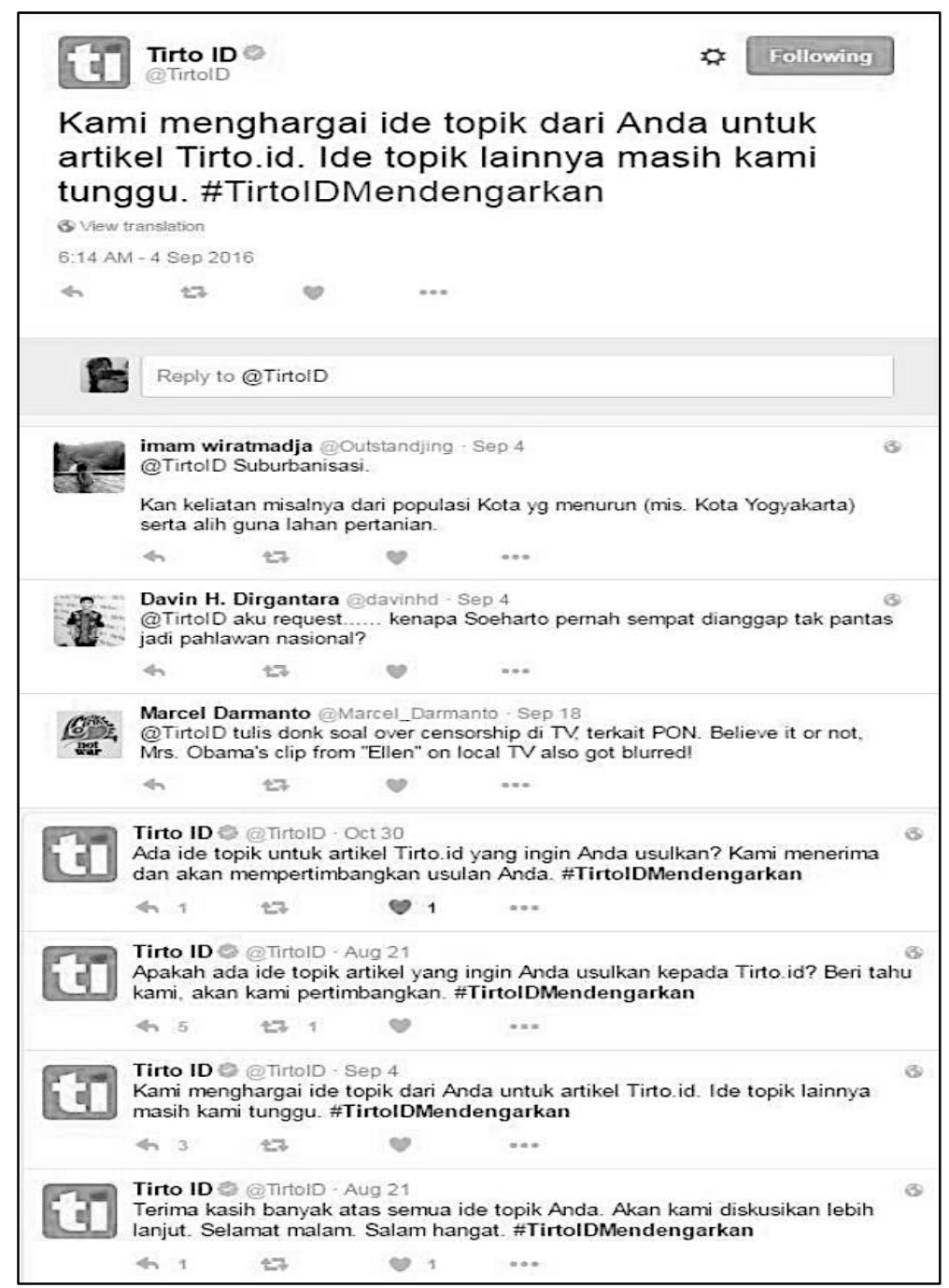

Gambar 2. Mendengarkan sebagai newsgathering

(Sumber: twitter@tirtoID)

Masukan yang diterima oleh Tirto.id melalui Twitter kemudian dipertimbangkan oleh tim redaksi untuk diperdalam dengan mencari tahu hal apa yang bisa digali lebih lanjut. Namun, jika dalam sebulan respons yang didapatkan hanya sedikit, reporter biasanya menggunakan strategi lain. Sebagai contoh, reporter dapat menggunakan akun pribadi. Melalui akun Twitter pribadi, reporter mengeluarkan tweet tentang suatu isu yang ingin ia jadikan berita. Sebelum mengeluarkan tweet, ia harus mencari tahu latar belakang isunya terlebih dahulu, misalkan sejarah atau riset terdahulu yang pernah membahas fenomena tersebut. Data tersebut akan ia baca, kemudian ia mencari narasumber pakar untuk menegaskan bahwa fenomena tersebut memang benar-benar ada. Dari proses panjang rapat redaksi dan riset pustaka, kemudian barulah ia mencari narasumber yang tepat.

Salah satu contohnya adalah pemberitaan tentang pengalaman walk-out saat khotbah Sholat Jum'at. Seorang reporter Tirto.id mengeluarkan pertanyaan melalui akun Facebook dan Twitter pribadinya untuk menanyakan pengalaman orang-orang yang pernah walk-out dari 
khotbah sholat Jum'at. Reporter tersebut menjelaskan: "Saya masih belum bisa ketemu sama orang-orang di sekitar sini yang walk-out. Jadi, kemudian saya tanyakan di Twitter, banyak responsnya dan saya melihat bahwa fenomena ini terjadi tidak hanya pada 1 orang saja atau saya sendiri, tapi banyak orang"

Dari dua media sosial berbeda untuk pencarian, respons yang didapat biasanya lebih cepat melalui Twitter dibandingkan Facebook. Melalui Twitter, pengikut dapat langsung menjawab. Sementara itu, repsons diperoleh dari Facebook pada umumnya memerlukan waktu sehari atau beberapa hari kemudian. Kecepatan Twitter membuat reporter umumnya memilih Twitter untuk newsgathering dalam hal mencari narasumber. Selain itu, newsgathering melalui Twitter dapat menghasilkan banyak respons dengan perspektif beragam dan potensial untuk digali. Jawaban-jawaban yang masuk kemudian diseleksi. Meski responsnya cepat, kendala yang didapatkan dari newsgathering dari Twitter adalah kredibilitas orang tersebut. Menurut seorang reporter, 'Kalau sudah ada 'centang biru' kan enak, berarti Twitter udah verified, kalau misalnya enggak kan susah. Belum lagi kalau akunnya avatarnya telur, follower-nya sedikit, nggak bisa saya pakai untuk narasumber"

Akun yang dipilih melalui fitur Direct Message Twitter, atau fitur bertukar pesan langsung secara personal antar-akun. Akun yang dipilih sebagai narasumber harus memenuhi beberapa syarat. Pertama, akun tersebut bukanlah akun anonim, dalam artian tersebut harus memiliki nama yang jelas. Kedua, akun tersebut harus memiliki identitas jelas, seperti nama, pekerjaan, alamat, atau nomor ponselnya. Ketiga, narasumber tersebut bersedia untuk ditulis di berita dengan nama asli, atau tidak dengan nama anonim.

Jika narasumber tersebut sudah memenuhi kriteria, maka akan dihubungi melalui telepon untuk kemudian dijadikan bahan berita. Tirto.id memiliki kebijakan untuk tetap melakukan wawancara secara tatap muka, tetapi untuk beberapa kasus, misalkan berita yang butuh segera, kadang mereka terkendala untuk menemui narasumber. Oleh karena itulah teknologi komunikasi digunakan. Hal tersebut dilakukan untuk memverifikasi narasumber yang ditemui benar-benar kredibel, akuntabilitasnya dapat dipertanggungjawabkan, dan memiliki kapasitas untuk bicara.

Jika narasumber yang dipilih dan diwawancarai mungkin saja tidak lolos pada saat proses verifikasi oleh redaktur, biasanya redaktur akan menanyakan kredibilitas narasumber tersebut, seperti latar belakangnya, tempat tinggalnya, pekerjaannya, hingga alasan mengapa narasumber tersebut berkata demikian. Hal tersebut sudah biasa terjadi di Tirto.id.

Head of Partership Twitter Indonesia Teguh Wicaksono mengatakan, Tirto.id memosisikan Twitter tidak hanya sebagai platform distribusi, tetapi juga sebagai alat newsgathering. Meskipun hal itu sederhana, menurutnya hal tersebut sangat fundamental, karena Tirto.id memperlakukan platform tersebut tidak hanya mendistribusikan konten, tetapi juga menyerap konten dan membuat sesuatu yang baru.

Selain menggunakan akun pribadinya, pekerja lain menggunakan Twitter untuk melihat traffic atau trending topics perbincangan yang ada di Twitter saat itu. Namun, hal tersebut harus dipastikan bebas dari robot karena ada banyaknya buzzer yang beredar. Tweet dari robot tersebut dieliminasi, kemudian tema yang organik baru dibahas dalam rapat. 
25 | Kajian Jurnalisme

ISSN 2549-0559 (cetak) ISSN 2549-1946 (online)

Volume 03 Nomor 01 Tahun 2019

Bagian berikut ini akan dijabarkan hasil analisis penggunaan Twitter sebagai medium distribusi berita, sarana komunikasi dua arah dengan audiens, dan alat newsgathering beserta penjabaran alur kerjanya melalui pengenalan pemikiran dan teori yang menjadi bingkai besar penelitian dan mengaitkannya sesuai konteks alur kerja Tirto.id berdasarkan konsep manajemen, mulai dari planning (perencanaan), organizing (pengorganisasian), actuating (pelaksanaan), hingga controlling (pengawasan).

\section{Planning/Perencanaan}

Pemimpin Redaksi sekaligus CEO Tirto.id Sapto Anggoro mengatakan, saat ia mendirikan Tirto.id di era informasi ini, banyak bacaan hoax yang menyesatkan. Ia membentuk Tirto.id dengan tujuan untuk memberikan bacaan yang mencerahkan dan dapat melawan hoax. Tirto.id pun memberikan bacaan berkualitas kepada generasi muda agar lebih paham dan kritis serta memiliki kehidupan literasi yang lebih sehat:

"Ketika orang semakin banyak hoax, dia butuh tuntunan. Dia butuh pegangan Butuh bacaan yang sehat. Butuh bacaan yang bisa mencerahkan. Dalam konteks itu Tirto.id berdiri. Kami siap melawan hoax, kami siap melawan orang-orang yang memang pengin mempersulit orang membaca, merumitkan orang membaca" (Wawancara dengan A. Sapto Anggoro pada 4 Januari 2017).

Peneliti menghubungkan pembentukan generasi yang Sapto inginkan dengan perubahan sosial yang dijelaskan oleh Agus Salim dalam bukunya yang berjudul Perubahan Sosial, Sketsa Teori dan Refleksi Metodologi Kasus Indonesia. Perubahan sosial, atau yang disebut juga dengan social shaping, mencakup berbagai aspek kehidupan masyarakat, termasuk pengetahuan yang kemudian dapat berpengaruh kepada budaya masyarakat secara luas (Salim, 2002).

Dennis McQuail dalam bukunya yang berjudul Teori Komunikasi Massa menyebutkan bahwa 'Komunikasi massa dapat dianggap sebagai fenomena 'masyarakat' dan 'budaya'. Lembaga media massa merupakan bagian dari struktur masyarakat, dan infrastruktur teknologinya adalah bagian dari dasar ekonomi dan kekuatan, sementara ide, citra, dan informasi disebarkan oleh media jelas merupakan aspek penting dari budaya kita" (McQuail, 2011:86).

Agar dapat mewujudkan social shaping tersebut, Tirto.id membuat sebuah bentuk nyata dari pembentukansosial dalam skala mikro. Level ini merujuk pada bagaimana pemilihan medium yang dilakukan dalam melakukan interaksi atau dalam situasi tertentu, media online. Seperti yang tertera pada laman resmi Tirto.id, pembentukan sosial atau social shaping tersebut dapat dipengaruhi oleh sumber informasi yang tersedia: Tirto.id percaya bahwa laporanlaporan yang tercipta dari kekuatan data, disampaikan secara baik, namun tak abai pada kecepatan adalah sumber informasi yang layak diperoleh oleh masyarakat Indonesia hari ini, terutama para pengambil keputusan, dan pengendali perubahan.

Bacaan yang berkualitas tersebut tidak dapat berdiri sendiri. Media harus memerhatikan ekosistemnya juga, dalam hal ini adalah teknologi yang digunakan. Tirto.id memilih untuk menggunakan teknologi komunikasi, yaitu media sosial sebagai medium. Kebijakan Tirto.id 
untuk menggunakan teknologi dalam bentuk media sosial merupakan apa yang diungkapkan oleh Agus Salim bahwa terdapat kekuatan eksternal yang memiliki pengaruh dalam social shaping. Salim mengungkapkan bahwa teknologi merupakan mesin penggerak (turbin) perubahan sosial, memiliki relevansi yang sangat tinggi dalam khasanah dalam perkembangan ilmu-ilmu sosial (Salim, 2002).

Tirto.id menggunakan beberapa media sosial sebagai medium, diantaranya adalah Facebook, Twitter, LinkedIn, Google+, Instagram, dan YouTube. Namun, seperti yang diakui oleh Pemimpin Redaksi sekaligus CEO Tirto.id A. Sapto Anggoro, Tirto.id paling aktif menggunakan Facebook dan Twitter untuk menyebarkan tautan berita.

Penggunaan keduanya menggunakan teknik yang sama, namun Tirto.id memiliki beberapa landasan untuk menggunakan Twitter sebagai medium pendistribusian berita. Pertama, kesesuaian medium distribusi dengan latar belakang Tirto.id sebagai media online; kedua, keinginan Tirto.id untuk berinovasi dengan Twitter; ketiga, kemudahan yang diberikan oleh Twitter; keempat, strategi Tirto.id dalam segi branding; dan kelima, kesesuaian dengan target pembaca Tirto.id.

Kelima alasan tersebut sesuai dengan pemikiran Marshall McLuhan mengenai ekologi media, yaitu "The study of media environments, the idea that technology and techniques, modes of information and codes of communication play a leading role in human affairs" (Richard, West; Turner, 2017). Ekologi media yang ingin disampaikan oleh McLuhan adalah sebuah kajian mengenai lingkungan media, di mana teknologi, teknik, dan berbagai mode informasi serta kode menjadi pemeran utama di dalam kehidupan manusia. Bisa dikatakan, teknologi memegang peranan penting di dalam masyarakat, karena dapat mengolah kehidupan masyarakat.

Mengacu pada pemikiran Marshall McLuhan, Physicologically, man in the normal use of technology (or his variously extended body) is perpetually modified by it and in turns finds ever new ways of modifying his technology (McLuhan, 1994). Manusia memang dimodifikasi oleh teknologi, namun pada akhirnya, manusia akan selalu mencari cara untuk mengubah kembali teknologi tersebut. Manusia akan kembali menjadi subjek, bukan hanya objek pasif yang terpapar oleh teknologi. Mengacu pada pernyataan McLuhan tersebut, memang manusia lah yang menciptakan Twitter. Namun, Tirto.id tidak hanya menjadi penggerak Twitter saja, tetapi Tirto.id menjadi pihak yang memodifikasi teknologi tersebut menjdi sebuah medium yang digunakan untuk kegiatan jurnalistik.

Tirto.id menggunakan Twitter sebagai medium distribusi berita dan newsgathering sebagai bentuk penguatan dari tubuh manusia. Sebelum memasuki era digital, manusia telah melewati The Writing Era, The Printing Era, Telecommunication Era, di mana dalam satu era, hanya ada satu indera yang dikuatkan. Misalnya, indera penglihatan pada Writing Era dan pendengaran pada Telecommunication Era. Namun, memasuki Interactive Communcation Era, penggunaan Twitter sebagai medium distribusi berita oleh Tirto.id memerlukan penggunaan beberapa indera sekaligus. Twitter dapat menggabungkan audio dan visual sekaligus dan menyertakan partisipasi audiens didalamnya. Berdasarkan hal tersebut, dan mengacu pada pemaparan McLuhan tentang "the artist" Twitter ditempatkan sebagai artefak atau teknologi 
27 | Kajian Jurnalisme

ISSN 2549-0559 (cetak) ISSN 2549-1946 (online)

Volume 03 Nomor 01 Tahun 2019

buatan manusia dan Tirto.id berperan sebagai seniman. Seniman tersebut menciptakan makna untuk menjembatani warisan biologis dari lingkungan yang tercipta dari sebuah inovasi teknologi, yaitu Twitter.

Pertimbangan Tirto.id untuk menempatkan Twitter sebagai artefak atau perpanjangan atau penguat tubuh manusia tersebut berada pada tahap perencanaan Tirto.id, yang berbentuk rapat. Berbagai pertimbangan dilakukan dan menghasilkan keputusan untuk menggunakan Twitter untuk menempuh kinerja dalam kegiatan jurnalistik.

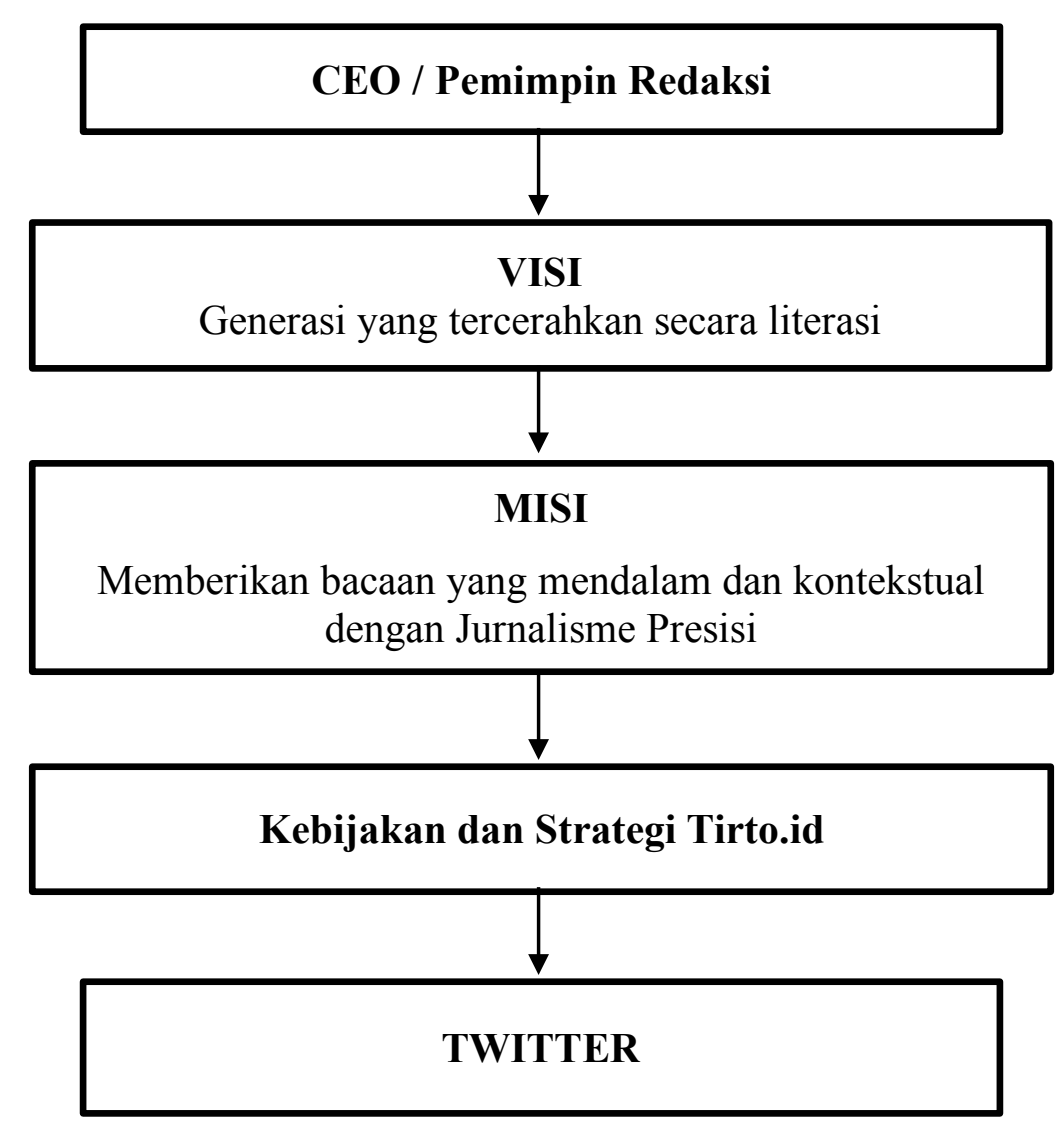

Gambar 3. Alur Pemikiran Tahap Perencanaan Tirto.id dalam Penggunaan Twitter (Sumber: Analisis Hasil Penelitian 2017)

\section{Organizing/Pengorganisasian}

Pemimpin Redaksi dan juga pemilik modal berkewenangan untuk mengatur manajemen, termasuk pembagian kerja. Ini juga termasuk sebagai pemanfaatan dari sumber daya manusia (men) yang dimiliki Tirto.id. Pembagian kerja sesuai posisinya masing-masing merupakan tahap kedua dalam prinsip dasar manajemen menurut Terry, yaitu organizing. Organizing, menurut Terry, adalah mengelompokkan dan menentukan berbagai kegiatan penting dan memberikan kekuasaan untuk melaksanakan kegiatan-kegiatan itu. Pada tahap ini, setiap pekerjaan ditetapkan secara teliti dan dibagi menjadi tugas setiap orang dalam tiap kelompok yang kemudian akan saling berhubungan. 
Bisa dikatakan, pada tahap organizing atau pengorganisasian ini, sumber daya manusia (SDM) ditempatkan sesuai dengan kapabilitasnya. Hal tersebut dilakukan oleh Tirto.id dalam pembagian tim kerja. Dalam penelitian ini, tim yang menangani berita adalah Tim Redaksi, sementara dalam penggunaan Twitter adalah Tim Marketing dan Sosial Media.

Tirto.id membuat kebijakan untuk membentuk tim media sosial yang terpisah dengan tim redaksi. Media sosial dipegang oleh tim tersendiri, Sofyan sebagai administrator akun resmi Twitter Tirto.id. Melalui pembagian kerja, menunjukkan bahwa dengan adanya peran penting teknologi dengan pemberian posisi khusus untuk media sosial. Pada tahap ini, pemanfaatan sumber daya tidak hanya sebatas manusia, tetapi juga mesin (machine) yang tersedia di Tirto.id. Mesin tersebut berupa teknologi informasi yang digunakan untuk mencapai tutjuan Tirto.id yang sudah ditetapkan sebelumnya, yaitu membuat bacaan yang berkualitas. Selain itu, machine tersebut berguna sebagai alat yang akan membantu men untuk mengelola materials.

Pada tahap pengorganisasian inilah, pekerjaan, pertanggungjawaban, dan luas kekuasaan ditentukan, yang berarti kewenangan tim media sosial ditentukan batasannya. Sapto pernah mengungkapkan bahwa ide marketing \#TirtoMagang yang dilakukan melalui Twitter merupakan inisiatif dari tim sosial media. Melalui pernyataan tersebut, Sapto memberikan porsi bagi tim media sosial untuk memberikan ide yang bisa dijalankan oleh Tirto.id bahwa Twitter bisa digunakan tidak hanya sebagai distribusi berita sebagai informasi, tetapi juga informasi lainnya.

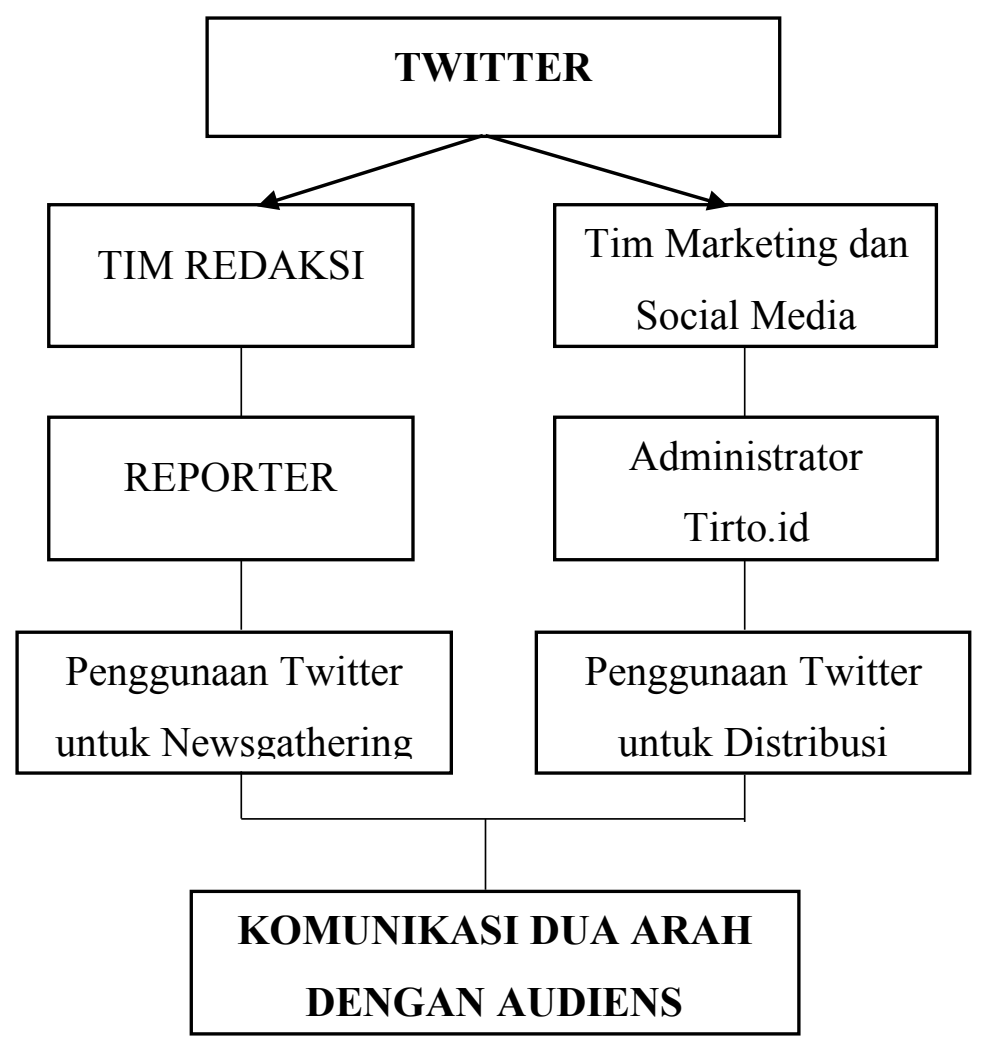

Gambar 4. Alur Pemikiran Tahap Pengorganisasian Penggunaan Twitter oleh Tirto.id (Sumber: Analisis Hasil Penelitian, 2017) 
29 | Kajian Jurnalisme

ISSN 2549-0559 (cetak) ISSN 2549-1946 (online)

Volume 03 Nomor 01 Tahun 2019

Pemisahan Tim Redaksi dan Tim Sosial Media tidak membuat keduanya bekerja terpisah. Sesuai dengan konteks penelitian, yaitu penggunaan teknologi komunikasi oleh perusahaan media massa, tentu kedua tim tersebut saling berhubungan, tanpa adanya tim yang lebih superior atau mendikte tim yang lain. Sapto memberikan kewenangan setiap tim sesuai keahliannya masing-masing.

\section{Actuating/Pelaksanaan}

Keterkaitan tim satu sama lain peneliti jelaskan dalam tahap ketiga dalam prinsip manajemen menurut Terry, yaitu actuating (pelaksanaan). Penggunaan Twitter oleh Tirto.id telah menggeser budaya komunikasi satu arah yang selama ini terjadi di antara media massa dan khalayaknya. Media massa kerap dianggap sebagai pengirim pesan dan khalayak dianggap sebagai penerima pesan yang pasif. Penggunaan Twitter oleh Tirto.id menggeser itu semua dan menjadikan adanya komunikasi dua arah yang terjadi antara Tirto.id dan khalayaknya.

Komunikasi dua arah yang terjadi diantara Tirto.id dan khalayaknya terjadi pada proses newsgathering. Tirto.id menggunakan Twitter, yaitu tweet dan fitur polling, untuk mendapatkan bahan berita. Melalui fitur polling, seperti apa yang Dhani ungkapkan: "Polling bukan jadi bahan berita per se, tapi itu jadi kayak misalnya lead awal kita. Kita ngasih polling untuk kemudian melihat respons masyarakat terhadap itu, baru kemudian kita eksplorasi apa yang bisa digarap dari tanggapan masyarakat itu" (Wawancara dengan Arman Dhani pada 31 Desember 2016).

Selain menggunakan fitur polling, Tirto.id juga sempat mencoba untuk memberikan kesempatan bagi pembaca untuk memberikan usulan ide atau topik yang ingin dibahas kepada Tirto.id melalui Twitter. Tirto.id menyebutnya sebagai \#TirtoIDMendengarkan. Namun, seperti apa yang diungkapkan oleh Sapto dan Dhani, ternyata respons audiens hanya sedikit. Penggunaan Twitter pada tahap actuating juga dimanfaatkan untuk mencari narasumber berita yang ditargetkan. Reporter Tirto.id memilih narasumber melalui reply atas tweet yang dikeluarkan mengenai topik beritanya. Kemudian juga menggunakan fitur Twitter, yaitu Direct Message untuk berkomunikasi dengan narasumber untuk menanyakan data sebagai keperluan wawancara. Setelah Tirto.id menggunakan Twitter untuk keperluan newsgathering, sesuai dengan alur kerja yang sudah peneliti paparkan, alur kerja kemudian dilanjutkan kepada penulisan berita. Pada kegiatan ini, Tirto.id tidak menggunakan Twitter. Namun, pada tahap selanjutnya, yaitu distribusi berita, barulah kemudian Tirto.id menggunakan kembali Twitter. Distribusi berita tersebut mengandalkan hyperlink yang dilampirkan dalam sebuah tweet.

Penggunaan hyperlink disebut oleh Mark Deuze sebagai hipertekstualitas. Hipertekstualitas adalah penggunaan hyperlink, atautautan dalam bahasa Indonesia, yang digunakan karena banyaknya teks yang saling terhubung satu sama lain. Dengan demikian, pembaca bisa mendapatkan beragam informasi dari sudut pandang yang beragam dan berbeda, cukup dengan membuka tautan yang ingin diakses. Mengena keterkaitan informasi satu sama lain, Nurlatifah menjelaskan:

"Fenomena ini sebenarnya karakter bawaan dari awal kemunculan World Wide Web (www). Sifat ini diadaptasi oleh situs-situs penyedia informasi (portal berita) untuk 
menyediakan berita asli sesuai yang diklik atau diinginkan oleh pembaca, sekaligus menghadirkan aspek lain yaitu link berita sejenis, atau teks berita yang asli atau dokumen pendukung lainnya" (Nurlatifah, 2012).

Hipertekstualitas tersebut turut diimplementasikan oleh Tirto.id, tidak hanya pada laman situsnya saja, tetapi juga pada tweet yang dikeluarkan melalui akun Twitter resmi Tirto.id. Pembaca hanya perlu meng-klik tautan yang tersedia, lalu pembaca akan diarahkan ke informasi yang diinginkan.

Seperti apa yang diungkapkan oleh reporter Tirto.id Arman Dhani mengenai penggunaan hyperlink, "Kalau di Instagram kita mungkin nggak bakal post banyak karena link, deskripsi link, itu kan nggak bisa di-klik" (Wawancara dengan Arman Dhani $\quad$ pada 30 Desember 2016). Penggunaan Instagram tidak dioptimalkan karena ketidakmampuannya dalam penggunaan hyperlink atau tautan untuk mendistribusikan berita. Namun tidak demikian dengan Facebook dan Twitter. Tirto.id menggunakan Facebook dan Twitter untuk menyebarkan tautan informasi. Bahkan, tautan yang digunakan pada Twitter tidak hanya tautan berita, tetapi juga tanda pagar, atau tagar, yang dapat mengumpulkan segala informasi tentang magang di Tirto.id dalam tagar \#TirtoDKI. Hal tersebut menunjukkan peran hyperlink dalam penyebaran informasi, tidak hanya berita, pada media online. Menurut Deuze, penggunaan hyperlink untuk dapat menyambungkan berbagai informasi yang tersedia dan bebas untuk diakses di internet dapat merubah peran jurnalis:

With the explosive increase of information on a worldwides scale, the necessity of offering information about information has become a crucial addition to the journalist's skills and tasks (Deuze, 1999). This redefines the journalist's role into an annotational or orientational one - a shift from watchdog to the 'guidedog' (Deuze, 2001).

Deuze menjelaskan bahwa dengan banyaknya informasi yang tersebar di mana-mana, pentingnya untuk menawarkan informasi atas informasi menjadi sebuah keahlian krusial lainnya yang harus dimiliki oleh seorang jurnalis. Hal tersebut mendefiniskan kembali peran jurnalis menjadi pihak pemberi informasi atau pengarah, yang merubah 'anjing penjaga' menjadi 'anjing pemandu'. Sesuai dengan visi Tirto.id untuk membuat bacaan yang mencerahkan, Tirto.id membuat kebijakan untuk membuat tulisan berbasis data yang disajikan secara komprehensif dan mendalam. Dalam satu berita, informasi bisa disajikan hingga 20 alinea. Namun, untuk mempermudah pembacanya untuk memahami.

Tirto.id tidak hanya mengandalkan hyperlink untuk pendistribusian berita, tetapi juga dalam bentuk infografis, foto, dan gambar bergerak (gif). Hal tersebut memungkinkan untuk Tirto.id lakukan karena Twitter pun mendukung untuk penggunaan multimedia. Bahkan, Tirto.id menggunakan fitur penggunaan video dalam tweet pada kegiatan Q\&A dalam rangka \#TanyaHarbolnas. Penggunaan berbagai jenis media yang digunakan oleh Tirto.id selaras dengan salah satu karakter jurnalisme online lain yang diungkapkan oleh Deuze, yaitu multimediality. Ia menjelaskannya sebagai: The presentation of a news story package on a website using two or more media formats, such as (but not limited) spoken and written word, music, moving and still images, graphic animations, including interactive and hypertextual elements (Deuze, 2004). Multimedia yang disinggung oleh Deuze adalah sebuah presentasi dari 
31 Kajian Jurnalisme

ISSN 2549-0559 (cetak) ISSN 2549-1946 (online)

Volume 03 Nomor 01 Tahun 2019

satu kesatuan sebuah berita dalam sebuah situs menggunakan dua atau lebih format media, seperti kata-kata yang ditulis atau dilisankan, musik, gambar diam atau gambar tetap, animasi, termasuk elemen hipertekstual dan interaktif.

Menurut Rulli Nasrullah dalam bukunya yang berjudul Media Siber, interaktivitas media baru memungkinkan adanya umpan balik langsung dan adanya transformasi dari batasan antara khalayak dan produsen informasi. Hal tersebut kemudian dijelaskan oleh Jan Van Dijk mengenai empat level pendekatan dari interaktivitas sebagai bagian dari karakteristik media baru. Umpan balik secara instan tersebut memungkinkan untuk terjadi karena adanya fitur reply pada Twitter yang dapat langsung diterima oleh akun bersangkutan yang di-mention dalam bentuk notifikasi. Hal tersebut pula yang terjadi pada akun resmi Twitter Tirto.id jika ada pengguna lain yang menggunakan fitur reply dan mention tersebut. Nasrullah memaknai interaktivitas dalam media baru tersebut: Ini bermakna bahwa pada media baru khalayak tidak sekadar ditempatkan sebagai objek yang menjadi sasaran dari pesan. Khayalak dan perubahan teknologi media serta pemaknaan terhadap medium telah memperbarui peran khalayak untuk menjadi lebih interaktif terhadap pesan itu (Nasrullah, 2016: 14).

Adanya kesempatan bagi khalayak untuk dapat berinteraksi secara langsung, tidak hanya dengan redaksi tetapi juga dengan narasumber yang didatangkan, mengindikasikan bahwa Tirto.id tidak menempatkan pembacanya sebagai objek yang menerima pesan saja, tetapi juga sebagai pihak yang mengirimkan pesan. Dengan demikian pula, Tirto.id juga tidak berperan sebagai pengirim pesan saja, namun juga penerima pesan. Hubungan khalayak dan media tidak selamanya berada dalam posisi tidak berimbang, ada kesadaran atas kekuatan khalayak yang jika ini disadari oleh khalayak itu sendiri bisa menjadi titik balik bagi khalayak untuk tidak menjadi objek, tetapi berubah menjadi subjek (Nasrullah, 2016).

Interaktivitas pembaca melalui Twitter Tirto.id, didasarkan pada hasil kajian Jan Van Dijk tentang interaktivitas dalam media baru ke dalam beberapa level pendekatan. Pertama, media interaktif dapat melibatkan komunikasi banyak pihak, atau disebut dengan multilateral communication. Cuitan Twitter dapat dilihat tidak hanya oleh satu pengguna, tapi banyak pengguna dalam waktu yang bersamaan. Setiap pengguna juga dapat memberikan respons kepada Tirto.id. Respons tersebut dapat berikan pada waktu yang bersamaan pada setiap anggota ataupun waktu lain yang ditentukan sendiri oleh para penggunanya tanpa menghambat proses komunikasi itu sendiri. Van Dijk menyebutnya sebagai tanda terjadinya sinkronisasi dalam dimensi waktu sebagai level pendekatan yang kedua. Respons atau reply yang diberikan oleh pengikut Tirto.id bisa diberikan pada waktu yang bersamaan dengan tweet yang dikeluarkan Tirto.id. Namun, bisa juga pengguna tidak langsung memberikan cuitan balasan di waktu yang bersamaan. Penundaan itu bisa dalam hitungan detik, menit, bahkan jam, namun tidak akan mengganggu proses komunikasi itu sendiri. Balasan, meski tertunda, akan tetap masuk ke dalam notifikasi dan tetap terbaca oleh Tirto.id. Pada level ketiga, terjadinya keleluasaan kontrol dari pengguna yang melakukan interaksi. Pada level ini, pengguna memasuki dimensi kebiasaan (behavioral) yang tidak membatasi peran sender dan receiver. Fungsi tersebut dapat saling bertukar selama proses interaksi berlangsung. Dalam hal ini, Tirto.id dapat menjadi sender, yaitu pengirim pesan dengan cuitan dan audiens menjadi 
penerima pesan, namun audiens juga dapat menjadi pengirim pesan dengan membalas cuitan dan Tirto.id menjadi penerima pesan.

Level ini paling terlihat dalam proses komunikasi dua arah yang terjadi antara administrator Tirto.id dengan seorang pembaca yang me-reply tweet Tirto.id dengan komentar. Bahkan, balasan tidak hanya terjadi sekali, namun beberapa tweet. Interaksi yang terjadi antara Tirto.id dan audiensnya termasuk sebagai Computer Mediated Communication (CMC) atau komunikasi yang termediasi dengan komputer. Terminologi tersebut sesuai dengan apa yang diungkapkan oleh John December (1997) sebagai proses komunikasi manusia melalui komputer yang melibatkan khalayak, tersituasi dalam konteks tertentu, di mana proses itu memanfaatkan media untuk tujuan tertentu (Nasrullah, 2016: 79). Proses komunikasi yang terjalin antara Tirto.id dan audiensnya, baik dalam kepentingan distribusi berita hingga medium komunikasi dua arah, termediasi oleh teknologi yang didesain, dibuat, dan digunakan untuk memungkinkan terjadinya pertukaran data dan informasi.

Komunikasi tersebut adalah bagian dari CMC karena memenuhi beberapa aspek CMC yang diungkapkan oleh Marc Smith (1995, dalam Nasrullah, 2016). Pertama, komunikasi atau interaksi di dunia siber tidak mengharuskan adanya keberadaan dan kesamaan antara pengguna media siber ketika fungsi interaksi tersebut berlangsung. Interaksi tidak harus berada di tempat dan waktu yang sama seperti komunikasi tatap muka atau telepon. Tirto.id dapat mengirimkan pesan dari mana saja asal terhubung dengan komputer atau internet, dan begitu pula audiensnya. Secara waktu pun interaksi tersebut dapat terjadi kapan saja. Tirto.id dapat mengeluarkan cuitan pada pagi hari, lalu audiens dapat memberikan respons di siang hari, kemudian Tirto.id dapat membalas respons tersebut di malam hari dan komunikasi tersebut tetap dapat terjadi.

Kedua, interaksi yang terjadi di media siber dapat dikondisikan, baik secara ruang ataupun waktu. Komunikasi bisa terjadi di dalam waktu yang sama (synchronous) atau berbeda (asynchronous). Berdasarkan Model Komunikasi Termediasi Komputer yang diadaptasi dari Sally Sielof Magnan, komunikasi yang terjadi antara Tirto.id dan audiensnya merupakan termasuk jenis asynchronous dalam bentuk teks karena dapat terjadi di waktu yang berbeda seperti yang sudah diungkapkan sebelumnya.

Ketiga, Smith mengungkapkan bahwa interaksi yang terjadi dalam dunia siber pada kenyataannya terjadi melalui medium teks. Aspek ini bisa diaplikasikan jika pesan yang dikirimkan Tirto.id dan audiens berbentuk teks. Namun, aspek ini tidak dapat diaplikasikan kepada kegiatan Q\&A yang dilakukan Tirto.id, karena respons dapat berupa video di mana ekspresi dan intonasi bisa menjadi penentu dalam penyampaian dan penerimaan pesan.

Keempat, interaksi yang terjadi tidak mensyaratkan adanya kesamaan seperti status atau tingkat pengetahuan. Siapapun dapat berkomentar, memberikan tanggapan atau masukan melalui fitur reply yang ada pada Twitter jika audiens ingin melakukan interaksi dengan Tirto.id. Hal tersebut sangat mungkin dilakukan karena penggunaan Twitter yang benar-benar tak terbatas. Meski tidak adanya batasan status tersebut, Smith kemudian menguraikan bahwa satu-satunya "kelas" yang ada yaitu apa yang disebut dengan administrator. Dengan demikian, bisa dikatakan administrator akun Twitter Tirto.id memiliki "kelas" yang berbeda. Namun, hal 
33 | Kajian Jurnalisme

ISSN 2549-0559 (cetak) ISSN 2549-1946 (online)

Volume 03 Nomor 01 Tahun 2019

itu hanya bersifat teknis dan pengatur lingkungan komunikasi yang secara teknis pula ditentukan oleh pengguna lain (Nasrullah, 2016: 81).

Interaksi yang dapat terjadi antara Tirto.id dan audiens juga termasuk apa yang dimaksud oleh Abd El-Basit Mahmoud dan Philip J. Auter dengan salah satu karakteristik CMC, yaitu selektivitas. Pengguna disediakan beberapa pilihan atau informasi yang ada. Semakin banyak pilihan yang pengguna miliki atau tersedia pada medium yang digunakan, maka semakin tinggi pula tingkat interaktivitas pengguna terhadap medium tersebut. Misalnya, pada distribusi berita Tirto.id dengan kicauan Twitter melalui penggunaan Twitter Moments oleh Tirto.id. Sebuah kicauan yang menggunakan Twitter Moments, pada pemberitaan Tirto.id, mampu memuat beberapa berita sekaligus di dalamnya. Pengguna dapat memilih berita yang ingin dibaca dengan mengklik tautan yang ingin dibacanya saja, tanpa terpapar berita lain yang tidak ingin dibacanya.

Selain pemilihan berita, pengguna juga dapat memilih bagaimana ingin berinteraksi dengan Tirto.id ataupun orang lain melalui fitur Twitter lainnya. Jika pengguna ingin memberikan tanggapan melalui Twitter, pengguna dapat mengklik tombol reply, atau jika ingin sekaligus menyebarkan tautan, pengguna dapat menggunakan tombol retweet. Hal lain yang dapat digunakan oleh pengguna juga adalah memberikan tanda 'suka' dengan tombol 'like'.

Namun, pengguna juga dapat tidak melakukan interaksi apapun dengan pesan yang dikirimkan oleh Tirto.id. Tanpa memberikan respons apapun terhadap kicauan Tirto.id, baik itu berbentuk berita ataupun pertanyaan reporter Tirto.id seputar isu berita. Misalkan pengguna ingin melakuakn interaksi, hal tersebut bisa dilakukan nanti di waktu berbeda. Hal tersebut yang dimaksud oleh Walther (1996) bahwa CMC merupakan sebuah setting impersonal bahwa partisipan dapat membuat batasan tersendiri untuk menentukan waktu untuk berinteraksi.

Trevor J. Pinch, Wiebe E. Bijker, dan Thomas P. Hughes menjelaskan dalam "The Social Construction of Technology System" bahwa teknologi tidak akan menjadi subjek penentu apa yang dilakukan oleh manusia atau masyarakat, tetapi manusia atau kelompok masyarakat tersebut yang akan memengaruhi dan membentuk teknologi. Penggunaan Twitter oleh Tirto.id sesuai dengan konsep kunci pertama dari teori SCOT, yaitu interpretative flexibility yang menunjukkan bahwa desain teknologi merupakan proses terbuka. Dengan demikian, hasil yang tercipta pun berbeda, tergantung pada keadaan sosial dari proses membangun teknologi itu sendiri. Mengacu pada konsep kunci pertama tersebut, Tirto.id telah menyusun tujuan, visi, dan misinya sendiri yang kemudian mempengaruhi kebijakan penggunaan Twitter. Dengan begitu, penggunaan Twitter oleh karyawan Tirto.id pun bisa jadi berbeda dengan media lainnya karena telah disesuaikan dengan rencananya sebelumnya. 
Volume 03 Nomor 01 Tahun 2019

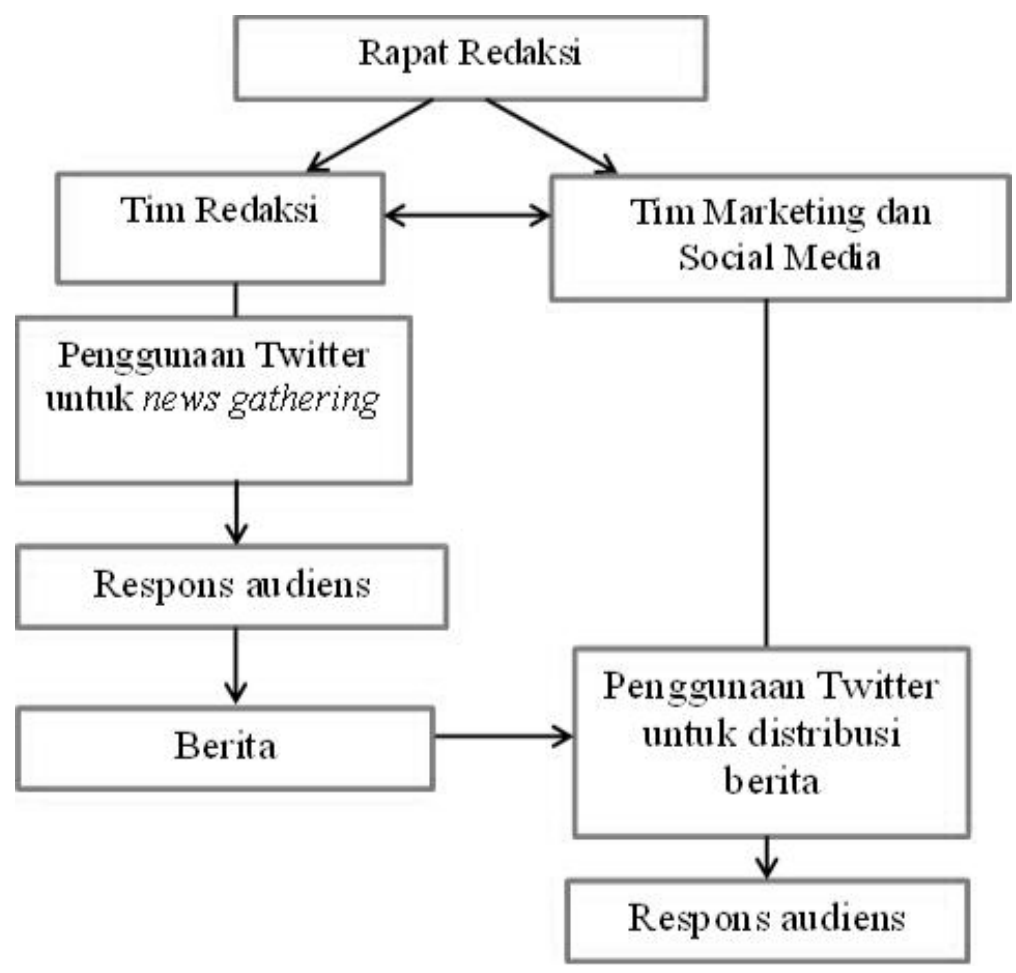

Gambar 5. Alur Pemikiran Tahap Actuating

(Sumber: Analisis Hasil Penelitian, 2017)

\section{Controlling/Pengawasan}

Feedback audiens melalui Twitter tersebut kemudian dibawa oleh Tirto.id ke dalam tahap keempat prinsip dasar manajemen Terry, yaitu controlling (pengawasan). Tahap ini mencakup kegiatan penetapan ukuran, monitor hasil dengan ukuran, memperbaiki penyimpangan, menyesuaikan dengan cara pengawasan sebelumnya. Tahap pengawasan ini berbentuk sebuah rapat evaluasi yang dilakukan oleh Tirto.id pada hari Jum'at. Pada tahap pengawasan ini pula dilakukan evaluasi terhadap hasil dengan ukuran. Hasil tersebut dapat berupa jumlah klik dan visit situs Tirto.id. Dalam penggunaan Twitter, ukuran tersebut juga dapat berupa reply dan retweet dari pengguna. Tidak hanya itu, jika melihat kembali tujuantujuan Tirto.id sesuai dengan ideologinya, maka ukuran tersebut juga bisa berbentuk tanggapan, masukan, atau kritik audiens yang disampaikan melalui Twitter.

Masukan dari audiens tersebut disampaikan oleh tim media sosial kepada tim redaksi di dalam rapat. Tim redaksi kemudian akan mempertimbangkan masukan tersebut. Jika memang sesuai, maka tim redaksi akan melakukan revisi. Dari hal tersebut, peneliti menyimpulkan bahwa tujuan Tirto.id untuk meningkatkan pemahaman pembaca hingga mampu mengkritisi berita Tirto.id melalui Twitter, telah berjalan sesuai harapan.

Seperti yang diungkapkan Sapto, ukuran hasil dalam bentuk visit dan rating yang didapatkan dari penggunaan hyperlink Tirto.id memang dibutuhkan, tetapi untuk saat ini, hasil tersebut tidak digunakan untuk mendapatkan iklan. Sapto menegaskan, "Kita bukannya nggak mau mendapatkan iklan, tapi kita Tirto.id pengin menunjukkan kepada masyarakat awal-awal 
35 | Kajian Jurnalisme

ISSN 2549-0559 (cetak) ISSN 2549-1946 (online)

Volume 03 Nomor 01 Tahun 2019

ini performance kita. Ini lho, Tirto.id. Ini lho, wajah kita. Sampai masyarakat faham, suka, senang, dan enjoy bersama Tirto.id, nah, dari situ akhirnya supaya banyak orang berkumpul dan tidak terganggu oleh iklan" (Wawancara dengan A. Sapto Anggoro pada 4 Januari 2017).

Tahap pengawasan tersebut bukanlah tahap terakhir dari manajemen karena tahap pengawasan akan mengawali tahap planning kembali. Seiring dengan berjalannya waktu, seperti apa yang diungkapkan Sofyan, Tirto.id masih terus belajar dan bereksperimen dalam penggunaan media sosialnya. Dari actuating tersebutlah hasil-hasil pengukuran didapatkan dan dijadikan bahan evaluasi.

Dari penggunaan teknologi Twitter oleh Tirto.id tersebut, kembali kepada pemikiran Salim bahwa teknologi merupakan salah satu mesin (turbin) penggerak social shaping. Perlakuan teknologi Twitter oleh Tirto.id termasuk sikap kelompok masyarakat yang menganggap memandang teknologi secara netral, tergantung pada kelompok masyarakat yang menggunakannya.

Perlakuan netral oleh Tirto.id tersebut peneliti lihat berdasarkan tiga aspek yang diungkapkan oleh Salim (2014). Pertama, dalam aspek kelembagaan dan organisasi, teknologi dapat diorganisasikan secara tepat untuk kepentingan masyarakat luas. Penggunaan Twitter ditujukan untuk membuat audiens lebih mudah menangkap penjelasan dari berita Tirto.id, baik melalui hyperlink, fitur Moments, fitur Q\&A, ataupun fitur reply, sehingga audiens memiliki generasi literasi yang lebih baik. Kedua, dilihat dari segi filosofi, bahwa teknologi netral adalah teknologi yang dibuat untuk mempermudah langkah-langkah manusia untuk mencapai tujuannya. Tirto.id memiliki tujuan untuk mempermudah proses newsgathering agar lebih efisien dan efektif, maupun komunikasi dua arah dan penyebaran berita yang lebih mudah. Dengan menggunakan Twitter pula, masyarakat lebih mudah memberikan respons kepada Tirto.id. Ketiga adalah aktivitas, di mana kegiatan teknologi adalah aktivitas inovasi yang digunakan untuk mengatasi masalah-masalah masyarakat. Tirto.id menganggap masyarakat kekurangan bahan bacaan yang berkualitas. Kegiatan tanya jawab menggunakan Twitter ataupun penggunaaan fitur Moments merupakan kegiatan inovasi demi menyelesaikan masalah masyarakat tersebut.

Apapun bentuknya, kerja merupakan respons manusia terhadap kebutuhan dan transformasi yang dibawa dalam kerja itu juga mentransformasikan kebutuhan manusia yang bisa menggerakkan manusia untuk menciptakan kebutuhan baru. Apa yang dilakukan Tirto.id dengan Twitter, yaitu medium distribusi berita dengan multimedia, serta menjadikannya sebagai alat newsgathering dan komunikasi dua arah, merupakan salah satu upaya Tirto.id untuk membuat pembaca nyaman dan mudah memahami berita, sehingga membuat perubahan yang lebih besar yaitu generasi yang lebih baik.

Dari keseluruhan hasil yang didapatkan, peneliti mencocokan kembali hasil tersebut dengan tetrad Laws of Media milik McLuhan. Penggunaan Twitter, sebagai teknologi komunikasi telah menunjukkan bahwa Twitter merupakan penguatan dari teknologi sebelumnya, yaitu komunikasi dua arah antara media massa dengan audiens yang terhubung melalui internet. Dilihat menggunakan hukum dari Laws of Media, poin ini merupakan poin extensions. 
Kajian Jurnalisme

ISSN 2549-0559 (cetak) ISSN 2549-1946 (online)

Volume 03 Nomor 01 Tahun 2019

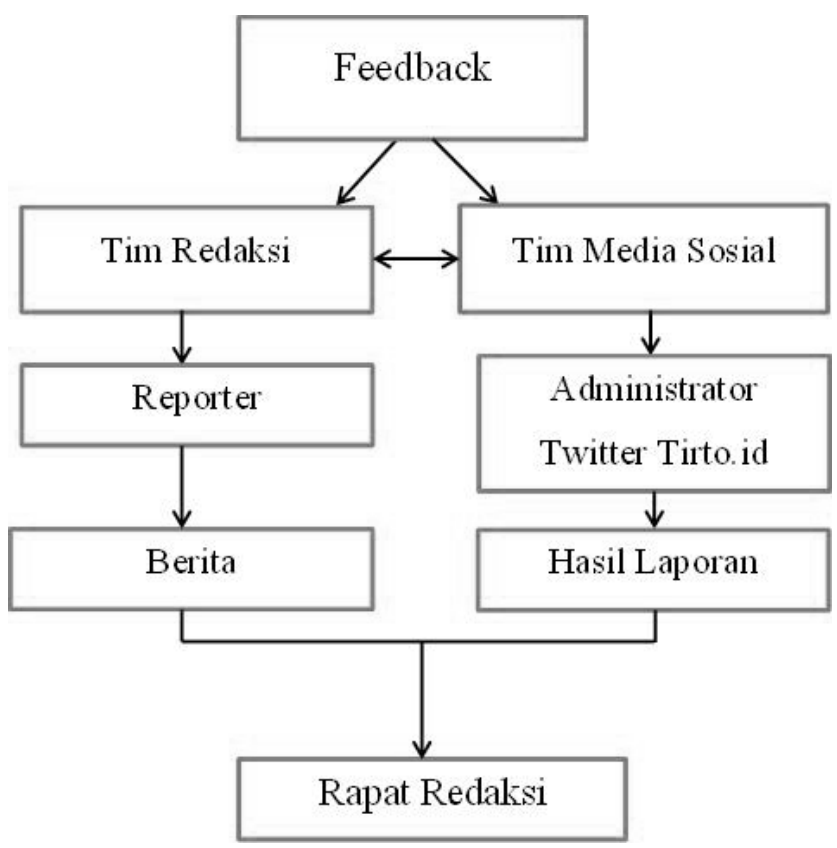

Gambar 6. Alur Pemikiran Tahap Controlling terhadap Penggunaan Twitter oleh Tirto.id

(Sumber: Analisis Hasil Penelitian)

Penggunaan Twitter oleh Tirto.id, seperti menautkan teks, audio, grafis, dan video dalam cuitannya merupakan sebuah bentuk multimedia. Pengguna multimedia dalam media baru adalah sebuah gabungan dari konten-konten yang biasanya hanya ada di media cetak, televisi, atau radio. Melalui penemuan tersebut, peneliti mengkaitkannya dengan hukum retrieval, yaitu ketika suatu artefak baru dapat membangkitkan kembali teknologi yang sebelumnya sudah ada.

Penggunaan teknologi komunikasi yang didasarkan oleh alasan Tirto.id, seperti memangkas waktu pengerjaan berita dengan berkomunikasi melalui internet menunjukkan bahwa Tirto.id meninggalkan beberapa tradisi atau budaya komunikasi dalam media massa, yaitu komunikasi tatap muka langsung. Ditinggalkannya budaya tersebut menunjukkan dengan menggunakan Twitter, Tirto.id meninggalkan budaya yang sudah dianggap usang, yang sesuai dengan hukum obsolete. Budaya baru, komunikasi melalui internet, telah membuat kinerja yang lebih efisien bagi pekerjanya tanpa harus repot turun ke lapangan untuk bertemu beberapa narasumber.

Selain itu, masih dalam poin obsolete, budaya komunikasi ini juga meninggalkan komunikasi satu arah yang selama ini berlangsung antara media massa dan audiensnya. Tirto.id menggunakan Twitter justru untuk menimbun respons dan feedback dari audiensnya, baik untuk kepentingan newsgathering yang berupa jawaban dari pertanyaan ataupun kepentingan distribusi berita yang berupa masukan-masukan. Penggunaan Twitter sebagai medium distribusi berita dan newsgathering yang mengandalkan komunikasi dua arah, dapat membuat adanya perang cuitan, atau tweet war, yang terjadi di antara audiens dan Tirto.id. Seperti apa yang diungkapkan oleh Sapto, komunikasi dua arah boleh saja dilakukan antara audiens dengan 
37 | Kajian Jurnalisme

ISSN 2549-0559 (cetak) ISSN 2549-1946 (online)

Volume 03 Nomor 01 Tahun 2019

pihak Tirto.id, namun ketika sudah mulai memanas, maka harus disudahi agar menjaga hubungan dengan audiens.

Adanya perang cuitan tersebut merupakan sebuah bentuk dari hukum reversal, yaitu sebuah keadaan di mana artefak tersebut justru memutarbalikkan keadaan. Ketika sebuah artefak seharusnya menjalankan fungsinya, yaitu Twitter sebagai medium distribusi berita dan newsgathering, namun justru menjadi arena perang cuitan.

\section{Simpulan}

Landasan Tirto.id dalam memilih saluran distribusi disesuaikan dengan latar belakang dan tujuan Tirto.id sebagai organisasi media massa. Tirto.id menggunakan media sosial Twitter sebagai alat penggerak perubahan sosial yang ingin dicapai, yaitu untuk meningkatkan pengetahuan generasi muda, tepatnya usia 18-35 tahun. Tirto.id merasa Twitter adalah teknologi yang tepat. Karena, Twitter memiliki beberapa keunggulan yang dapat membantu Tirto.id menyebarkan informasi, yaitu kecepatan dan kemudahan penyebaran berita serta komunikasi dua arah. Berdasar pemikiran Eric McLuhan, Tirto.id adalah seniman yang menggunakan Twitter sebagai perpanjangan tubuh manusia untuk menjalankan fungsinya.

Penggunaan Twitter oleh Tirto.id sebagai alat penggerak perubahan sosial melewati berbagai kebijakan manajemen yang dibuat oleh pemilik modal. Divisi yang pekerjaannya berkenaan dengan penggunaan Twitter adalah Tim Redaksi dan Tim Media Sosial. Tim redaksi, terutama wartawannya, menggunakan Twitter untuk proses pengumpulan berita. Sementara itu, Tim Marketing dan Social Media mendapat kewenangan untuk menjadi administrator akun resmi Twitter Tirto.id. Kinerja keduanya saling berkaitan. Proses kerja tersebut diawali oleh rapat perencanaan di Hari Senin untuk membahas proyeksi isu berita. Reporter kemudian menggunakan Twitter untuk melempar isu dan mencari narasumber sebelum akhirnya berita ditulis dan diperiksa oleh editor. Berita yang sudah jadi akan administrator sebarkan melalui Twitter dengan jeda setiap 30 menit. Respon audiens, dalam bentuk kritikan atau saran terhadap berita tersebut, akan administrator sampaikan kepada tim redaksi pada rapat evaluasi. Kebijakan akan kembali menyesuaikan sesuai evaluasi tersebut. Penggunaan Twitter sebagai medium newsgathering dilakukan dengan menggunakan Twitter untuk melempar isu kepada masyarakat untuk mencari narasumber. Kemudian, menyeleksi narasumber yang dipilih dengan melihat kredibilitas pengguna, seperti nama akun, identitas pengguna, dan avatar pengguna. Penggunaan Twitter untuk mencari perspektif isu dan narasumber membuat pekerjaan reporter menjadi lebih efisien dengan mengandalkan interaktivitas dan respons audiens yang lebih cepat.

Komunikasi dua arah yang terjadi akan menjadi bahan evaluasi bagi tim redaksi dan media sosial. Tirto.id membuka kesempatan bagi audiens untuk memberikan masukan, tanggapan, atau kritikan melalui Twitter. Jika memang sesuai, tim redaksi dapat mempertimbangkan masukan. Bahkan, Tirto.id memungkinkan audiens untuk berkomunikasi dengan reporter atau editor. Sesuai dengan pemikiran Eric McLuhan, penggunaan Twitter oleh Tirto.id mencakup empat hukum Laws of Media, yaitu sebagai penguat dari komunikasi massa yang terjalin dua arah antara media massa dengan audiens (extension), membangkitkan 
Kajian Jurnalisme

ISSN 2549-0559 (cetak) ISSN 2549-1946 (online)

Volume 03 Nomor 01 Tahun 2019

kembali kegunaan media massa tradisional (retrieve), meninggalkan budaya lama komunikasi massa dan tatap muka (make obsolete), namun jika digunakan berlebihan akan memicu perang cuitan (reversal).

\section{Daftar Pustaka}

Deuze, M. (2004). What is Multimedia Journalism. Journalism Studies, 5(2), 139-152. https://doi.org/10.1080/1461670042000211131

Eddyono, Subarkah, A. (2013). TWITTER: KAWAN, SEKALIGUS LAWAN BAGI REDAKSI BERITA. Journal Communication Spectrum, 3 (1), 47-65. Retrieved from http://journal.bakrie.ac.id/index.php/Journal_Communication_spectrum/article/viewFi $1 \mathrm{e} / 766 / 617$

Elcom. (2010). Twitter: Best Social Networking. Andi.

McLuhan, M. (1994). Understanding Media: The Extension of Man (T. W. Gordon, Ed.). McGraw-Hill.

McQuail, D. (2011). Teori Komunikasi Massa (6th ed.). Salemba Humanika.

Moleong, L. (2010). Metodologi Penelitian Kualitatif. Remaja Rosdakarya.

Morissan; Wardhani, Andi, Corry; Hamid, F. (2013). Teori Komunikasi Massa. Ghalia, Indonesia.

Nasrullah, R. (2016). Teori dan Riset Media Siber. Kencana.

Nugraha, B., \& Akbar, M. F. (2019). PERILAKU KOMUNIKASI PENGGUNA AKTIF INSTAGRAM. Jurnal Manajemen Komunikasi, 2(2), 95. https://doi.org/10.24198/jmk.v2i2.21330

Richard, West; Turner, H. L. (2017). Pengantar Teori Komunikasi: Analisis dan Aplikasi. Salemba Humanika.

Salim, A. (2002). Perubahan Sosial: Sketsa Teori dan Refleksi Metodologi Kasus Indonesia. Yogyakarta: Tiara Wacana.

Tirto.id. (2016). Jernih, Mengalir, Mencerahkan bersama Tirto.id. Retrieved July 15, 2019, from https://tirto.id/insider/about-us 